"Factors affecting the performance of small and medium enterprises in KwaZuluNatal, South Africa"

\begin{tabular}{ll} 
AUTHORS & $\begin{array}{l}\text { Sharmilee Sitharam } \\
\text { Muhammad Hoque }\end{array}$ \\
\hline ARTICLE INFO & $\begin{array}{l}\text { Sharmilee Sitharam and Muhammad Hoque (2016). Factors affecting the } \\
\text { performance of small and medium enterprises in KwaZulu-Natal, South Africa. } \\
\text { Problems and Perspectives in Management, 14(2-2), 277-288. } \\
\text { doi:10.21511/ppm.14(2-2).2016.03 }\end{array}$ \\
\hline DOI & http://dx.doi.org/10.21511/ppm.14(2-2).2016.03 \\
\hline RELEASED ON & Monday, 13 June 2016 \\
\hline JOURNAL & "Problems and Perspectives in Management" \\
\hline FOUNDER & LLC "Consulting Publishing Company "Business Perspectives"
\end{tabular}

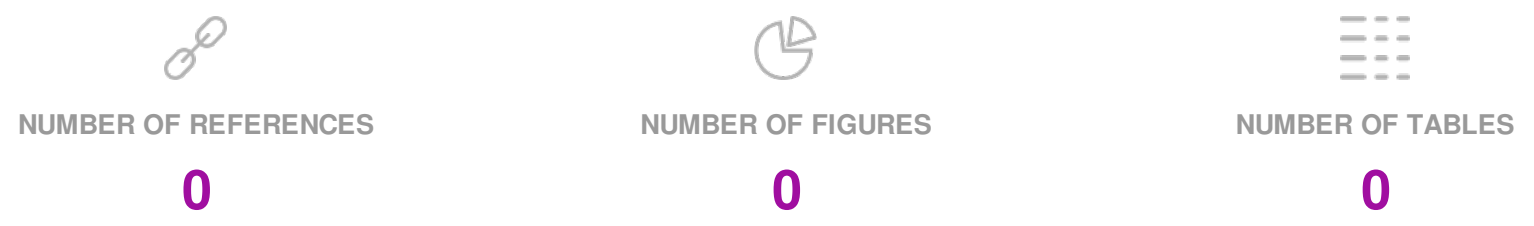

(C) The author(s) 2023. This publication is an open access article. 


\title{
Factors affecting the performance of small and medium enterprises in KwaZulu-Natal, South Africa
}

\begin{abstract}
Small and medium enterprises (SMEs) have an important role to play in the development of the country. A strong SME sector contributes highly to the economy, contributing to the gross domestic product, by reducing the level of unemployment, reduction in poverty levels and promotion of entrepreneurship activity. In South Africa (SA), the growth of SMEs and prevalence of SMEs is significantly low. Therefore, the aim of the study is to identify the internal and external factors affecting the performance of SMEs in KwaZulu-Natal, SA. This was a cross-sectional study conducted among 74 SMEs owners/managers who were members of the Durban Chamber of Commerce via online using anonymous questionnaire. The results revealed technological advancement would improve the performance of the business. With regards to challenge, the majority of the respondents viewed competition as a major challenge. Almost all the respondent indicated that crime and corruption affecting business performance. Competition was the only factor amongst the studied internal and external factors that revealed a significant association with the performance of SMEs in KwaZulu-Natal $(p=0.011)$. SMEs need to recognize they must prepare for both domestic and international competition. Collaboration between SMEs could be a way for SMEs to confront competition.
\end{abstract}

Keywords: competition, technological advancement, crime and corruption, challenges, performance.

JEL Classification: G20, L00, M00, M10, M12.

\section{Introduction}

A strong small and medium enterprises (SMEs) sector contributes highly to the country's economy, contributing to the gross domestic product (GDP) by reducing the level of unemployment, reduction in poverty levels and promotion of entrepreneurship activity. The role of SMEs in the development of the country is significant (Bayati \& Taghavi, 2007). SMEs in South Africa (SA) and across the globe still encounter many challenges, despite their importance and significance of SMEs and their contribution to economic growth which hinder business growth. It is obvious that hurdles in the business success are far more than it was previously. The environments, as well as some factors, are very complex and dynamic.

SMEs have the ability to make a meaningful reduction in the high level of unemployment and contribute to the GDP of the local economy in SA. Besides assisting in curbing the high level of unemployment, SMEs can be used as a means of transforming the country, by redistributing the productive assets, amongst the previously disadvantaged. The failure rate of SMEs is high throughout the world with the situation being no different to SA (Fang, Yuli \& Hongzhi, 2009).

Failure of SMEs in SA may be attributed to many factors and entrepreneurial culture. Given this state of SMEs in SA, the need exists to establish the hindering factors to improve/enhance SA's SME performance. Therefore, the objective of this study was to identify

(C) Sharmilee Sitharam, Muhammad Hoque, 2016.

Sharmilee Sitharam, Graduate School of Business and Leadership, University of KwaZulu-Natal, Westville Campus, Durban, South Africa. Muhammad Hoque, Graduate School of Business and Leadership, University of KwaZulu-Natal, Westville Campus, Durban, South Africa. factors that are responsible for the affecting the performance of SMEs in KwaZulu-Natal (KZN), SA.

\section{Literature review}

The economic growth and development of SME sector in SA continues to be affected by various challenging factors. Study by the Global Entrepreneurship Monitor (GEM) Reports (20012010), SME survival is one of the lowest in the world (Herrington, Kew \& Kew, 2010a). Growth rates of small businesses in South Africa are low, with an average of $50 \%$ of fail to grow. A lot of factors increase their influence and causing a huge effect on the success of SMEs (Cacciotti \& Hayton, 2015).

1.1. Definition of SME. Defining an SME can be challenging, as the term includes a wide array of definitions globally. When defining SMEs, countries and businesses often use their own judgment, using the asset value of the company, number of people employed, annual turnover generated.

The National Small Business Act 102 of 1996, p. 17, defines SMME as "small business" means a separate and distinct business entity, including cooperative enterprises and non-governmental organizations, managed by one owner or more which, including its branches or subsidiaries, if any, is predominantly carried on in any sector or subsector of the economy. In SA, 'SMME' and 'SME' are terms used interchangeably. The National Small Business Act further subdivides small business as survivalist, micro, very small, small and medium enterprises (NCR, 2011). In the Table below, the National Small Business Act uses the number of employees combined with the annual turnover, assets excluding fixed property, per enterprise size category to define SMEs: 
Table 1. Broad definitions of SMMEs in the National Small Business Act

\begin{tabular}{|l|l|l|l|}
\hline \multicolumn{4}{|c|}{ Definitions of SMMEs given in the National Small Business Act } \\
\hline Enterprise size & \multicolumn{1}{|c|}{ Number of employees } & \multicolumn{1}{c|}{ Annual turnover } & \multicolumn{1}{c|}{ Gross assets, excluding fixed property } \\
\hline Medium & $\begin{array}{l}\text { Fewer than } 100 \text { to 200, depending } \\
\text { on industry }\end{array}$ & $\begin{array}{l}\text { Less than R4 million to R50 million, } \\
\text { depending upon industry }\end{array}$ & $\begin{array}{l}\text { Less than R2 million to R18 million, depending } \\
\text { on industry }\end{array}$ \\
\hline Small & Fewer than 50 & $\begin{array}{l}\text { Less than R2 million to R25 million, } \\
\text { depending on industry }\end{array}$ & $\begin{array}{l}\text { Less than R2 million to R4,5 million, depending } \\
\text { on industry }\end{array}$ \\
\hline Very small & $\begin{array}{l}\text { Fewer than } 10 \text { to 20, depending } \\
\text { on industry }\end{array}$ & $\begin{array}{l}\text { Less than R200 000 to R500 000, } \\
\text { depending on industry }\end{array}$ & $\begin{array}{l}\text { Less than R150 000 to R500 000, depending on } \\
\text { industry }\end{array}$ \\
\hline Micro & Fewer than 5 & Less than R150 000 & Less than R100 000 \\
\hline
\end{tabular}

Adapted from National Small Business Act as cited by Falkena et al. (2001).

1.2. SMEs in the South African economy. Entrepreneurship is a precondition for any business. SA is lagging behind its peers (Xavier, Kelley, Kew, Herrington \& Vorderwuibecke, 2012). The youth of SA and the youth of Angola, Botswana, Ethiopia, Ghana, Malawi, Namibia, Nigeria, Uganda and Zambia were compared in a GEM survey in 2012, where the rate of perceived opportunities for SA came in at 39\%, well below the average of $70 \%$ for sub-Saharan Africa. In SA, SMEs stretch across all sectors of the economy (FinMark, 2010).

1.3. Factors affecting SMEs. The business environment is defined as factors both inside and outside the organzation, influencing the continued and successful existence of the organzation. The business environment is considered to play a crucial role in the growth of SMEs (Delmar \& Wiklund, 2008). Factors inside the business are known as internal environment and factors outside the business are the external environment. According to Beck and Demirguc-Kurt (2006), the growth of both internal and external environment is important for SME growth. Growth of SMEs will be negatively or positively influenced by changes in the business environment (World Bank, 2006; Zhang, van Doorn \& Leeflang, 2014).

1.4. Internal environment factors. The internal environment includes factors in the business environment that are largely controllable by the business (Fatoki \& Garwe, 2010; Kolstad \& Wiig, 2015). Challenges in the internal environment of a business, includes management competency and skills, limited financial knowledge and a lack of business management training, technological capabilities. The literature will discuss the internal environment factors, which include various factors, namely: managerial competency and skill, access to finance and technological capabilities.

1.5. Managerial competency and skills. Managerial competencies, have a positive influence on the performance of SMEs. Managerial experience, education, knowledge and start-up experience are used to measure managerial competencies (Hisrich \& Drnovsek, 2002). In a study where the importance of management competence in SMEs success was investigated, lack of managerial competency was found to be the main reason why SMEs fail (Martin \& Staines, 2008). Abdel, Rowena \& Robyn (2010) revealed that small business owner-managers have very basic understanding of financial and accounting information and have serious problems with financial planning literacy. On the same theme, it has been asserted that small and micro enterprises owner managers have little knowledge about financial matters, and found out that those with little or limited financial planning skills do not even value the information extracted from financial statements (Alattar, Kouhy \& Innes, 2009).

1.6. Access to finance. One of the major challenges pointed out as hindering the growth and survival of start-up SMEs in SA is access to finance (Mazanai \& Fatoki, 2012). Financial institutions credit processing has become more complex, and the institutions have become more cautious because of the financial crises, making it difficult for SMEs to understand the procedures and decisions when it comes to the loan processing (Haron et al., 2013). Before the crisis, access to finance was already seen as a concern to SMEs in many developing countries, accessing the funding that they needed to grow and expand. Banks do not provide SMEs with adequate capital in many of these countries (Dalberg, 2011). Pretorius \& Shaw (2004) observe that a vast majority of SMEs rely on internal finance, such as contribution from the owners, family and friends, which is often inadequate for SMEs to survive and grow. Therefore, access to external finance is necessary to reduce the impact of cash flow problems for SMEs.

1.7. Technological capabilities. The primary reasons small businesses continue to face growth challenges in developing countries, despite significant support from governments and other organizations, is their technological capabilities or lack thereof (Arinaitwe, 2006). Small businesses are still hindered by their lack of technological implementation, despite great technological advancements globally. Without this technology, these small businesses find it difficult to neither compete, nor grow (Arinaitwe, 2006). SMEs around the world, like in China and India, face common challenges being upgrading technology and 
building product quality. China, with its abundance of cheap labor, has the comparative advantage in the labor-intensive, low cost industries. The operation of many of the Indian SMEs is low scale production which reduces their ability to reduce costs of products and engage in technological upgrades, which is a major obstacle (Singh, Garg \& Deshmukh, 2010).

1.8. External environment factors. Factors such as economic variables and markets; crime and corruption, labor, infrastructure and regulations make up the external environment (Fatoki \& Garwe, 2010). In a comparative research between Nigeria and UK, Ihua (2009) found that economic growth of Nigerian SMEs were hindered by externally related factors, like the poor economic conditions and infrastructural inadequacy.

1.9. Competition. Businesses have to make decisions which deal not only with business survival opportunities, but also with business development in a changing environment under dynamic competitive conditions where each competitor tries to do impossible things to survive (Scarborough et al., 2009). The competitive standards change continuously due to consumers changing needs and expectations, technological developments and globalization of markets. Over the years, competition among SMEs has increased radically. Competition and sustainability for SMEs involve factors such as changing market trends, changing technologies and emerging new management and organizational techniques. SME survival is increasingly dependent on a number of factors including resilience of SMEs to refocus some of their strategies and technologies (Gunasekaran, Rai \& Griffin, 2011).

1.10. Globalization. Small businesses can no longer consider themselves to be strictly domestic businesses in the competitive global environment. For businesses across the globe, going global is not a preference or a matter of choice, but rather a necessity. Failure to cultivate global markets can be lethal mistake for modern businesses, whatever their size. To be successful business must consider themselves to be businesses without borders. Going global can put a tremendous strain on a small company (Scarborough et al., 2009). Though the trend toward the convergence has been developing for some time, the pace seems to be quickening, creating global opportunities and competition that did not exist even a few years ago. With the astounding rate of economic growth in countries such as China and India, a small business owner would be unwise to ignore overseas opportunities (Longenecker, 2012).

1.11. Regulatory factors. The success of the small business sector is continuously threatened by poor allocation of resources and over-regulation
(Chamberlain \& Smith, 2006). Regulations governing establishment of businesses are extremely intricate and conflicting. Mollentz (2002) argued that some SMMEs do not comply, because of some regulations being time-consuming and expensive. However, most SMMEs do not understand the laws that govern them, making it difficult to be compliant. South Africa's SMEs owners are losing confidence that the country's rigid labor laws are conducive to business growth. With regards to government policy, the country rates among the worst in the world in terms of labor market efficiency. Labor regulations are currently ranked as one of the most restrictive factors for doing business in South Africa for businesses dependent on labor. South Africa has extremely restrictive labor policies and the new labor regulations being promulgated have been slated as being even more restrictive than the existing problematic policies in place (Herrington, Kew \& Kew, 2010b).

1.12. Macroeconomic factors. Van Eeden, Viviers \& Venter (2003) found that macro-environmental issues such as inflation, interest rates and unemployment were the main factors negatively affecting the success of small businesses in four major urban areas in SA. Weak rand and high inflation rates are some of the characteristics of SA economic environment. Global economic downturn has been one of the reasons for the country's economic decline (Ehlers \& Lazenby, 2007). The rand has depreciated by about $5 \%$ to the dollar since the beginning of 2014 (Maswanganyi, 2014). Macroeconomic variable inflation results in the increase of expenses which again reduces the profits of SMEs and diverts investment to ensure the growth and success of the business. Inflation not only affects SMEs, but also their consumers, as it increases the costs of goods and decreases their disposable income (Cant \& Wiid, 2013).

1.13. Crime and corruption. In South Africa, the corruption rate is high, compared to developed countries (Transparency International, 2008). Transparency International's (TI) 2013 annual global corruption perception index (CPI) shows that SA has dropped 34 places since 2001. Out of 175 countries, SA ranks at number 72 (Corruption Watch, 2013). According to the GEM report corruption is becoming more prevalent, impacting the enterprises ability to survive and grow in SA, while the high levels of crime are affecting all business (Xavier, Kelley, Kew, Herrington \& Vorderwuibecke, 2012). In a survey of SMEs in Mexico, more than $50 \%$ of those interviewed saw their business severely negatively affected by corrupt practices (UNIDO, 2007). 


\section{Research methodology}

This was a cross-sectional study conducted among all the SMEs registered with Durban Chamber of Commerce. There are about 2000 SMEs that are registered with the Durban Chamber of Commerce. The recommended sample size for this study was obtained from the generalized scientific guideline for sample size decisions developed by Krejcie \& Morgan (1970), as cited in Sekaran \& Bougie (2010). By applying this model, a minimum sample size for the study was 325 .

2.1. Questionnaire and data collection. For data collection, a questionnaire was developed to answer the research question. The questionnaire had three sections. The first section contained sociodemographic details of respondents. Second section consisted of the internal environment factors affecting the performance of SMEs, and the last section had questions related to the external environment factors affecting the performance of SMEs.

The questions were short, simple and unambiguous. A variety of measurement scales were used which included dichotomous questions and Likert questions. Majority of the questionnaire was based on Likertscaling as this proved to be most appropriate for the study. As noted by Sekaran \& Bougie (2010), Likert scaling is one of the most frequently used numerical scales to measure attributes and behaviors in an organizational research.

Data were sent and collected using online survey method by using QuestionPro software. The selfadministered questionnaire was sent to randomly selected participants. The questionnaires were administered between 11 August 2014 and 11th of September 2014. Three reminders were sent after a week to ensure that proper follow-up on the responses.

2.2. Reliability and validity. Reliability, in quantitative research, refers to whether the result is replicable, the extent to which results are consistent over time and an accurate representation of the total population under study. If the results of a study can be reproduced under a similar methodology, then, the research instrument is considered to be reliable (Joppe, 2000). The method that is commonly used as a measure of reliability is Cronbach's Alpha. The Cronbach's Alpha measure was above 0.70 in this study which is an acceptable measure of reliability.

Validity, in quantitative research, refers to whether the means of measurement are accurate and whether they are actually measuring what they are intended to measure (Joppe, 2000). Pre-test, according to Schindler \& Cooper (2006), is described as a final step towards improving survey results. The researcher used MBA students to evaluate the appropriateness of questionnaires, and a pre-test was conducted on respondents who were not an element of this study. There were no major areas of concerns that were noted or experienced, and the data received were reconciled with what it was planned to collect.

2.3. Ethical considerations. Various ethical actions were performed during this research study. Firstly, ethical clearance for the study was granted by the University of KwaZulu-Natal Humanities and Social Sciences Research Ethics Committee (Reference Number: HSS/0575/014M). Secondly, a gatekeeper's letter was obtained from the Chief Executive Officer of the Durban Chamber of Commerce.

2.4. Data analysis. Data were initially completed online in QuestionPro program and later on imported to SPSS 21.0 version for analysis. The demographics variables are summarized using descriptive summary measures: expressed as mean (standard deviation) for continuous variables, and percent for categorical variables. Chi-squared test of association was carried out to find significant factors business performance. All statistical tests were performed using two-sided tests at the 0.05 level of significance. P-values were reported to three decimal places with values less than 0.001 being reported as, 0.001 . $\mathrm{P}$ values of less than 0.05 were considered statistically significant.

\section{Results and discussion}

A total of 325 questionnaires were emailed to the samples. Only 74 completed the questionnaire. Therefore, the response rate was $22.77 \%$.

Table 2 summarizes socio-demographic information of the participants. Majority of the SME owners/managers were males, indicating that majority of the SMEs in KZN were dominated by males. The demographic results of the study, reflects that the SME owners or managers were Whites (40.28\%) and Asians (41.67\%). While the SME sector is a one way of uplifting the previously disadvantaged, this would be difficult to achieve if Blacks and Coloureds continue to own or manage a small percentage of the SME sector.

The average age of the SME owners/managers was found to be 45.8 years. The oldest SME owner or manager was 68 years of age and the youngest was 20 years old, with a standard deviation of 11 years (Table 2).

Table 2. Socio-demographic information of the participants

\begin{tabular}{|l|c|c|}
\hline \multicolumn{1}{|c|}{ Variables } & Frequency & Percentage \\
\hline Gender & \multicolumn{2}{|c|}{} \\
\hline Male & 57 & 77.03 \\
\hline Female & 17 & 22.97 \\
\hline
\end{tabular}


Table 2 (cont.). Socio-demographic information of the participants

\begin{tabular}{|l|c|c|}
\hline \multicolumn{1}{|c|}{ Variables } & Frequency & Percentage \\
\hline Racial status & 13 & 17.57 \\
\hline Black & 30 & 40.54 \\
\hline Asian & 1 & 1.35 \\
\hline Coloured & 30 & 40.54 \\
\hline White \\
\hline Role in the business \\
\hline Owner \\
\hline Manager & 29 & 39.19 \\
\hline Both & 15 & 20.27 \\
\hline Other & 23 & 31.08 \\
\hline Level of education & 7 & 9.46 \\
\hline No formal education & 1 & \\
\hline Primary & 1 & 1.35 \\
\hline Secondary & 3 & 1.35 \\
\hline Matric / grade 12 & 5 & 6.05 \\
\hline Certificate / diploma & 26 & 35.14 \\
\hline Degree & 38 & 51.35 \\
\hline
\end{tabular}

All of the SME owners/managers had some form of education, and more than half of the respondents (52.78\%) had a Degree. Leitao \& Franco (2011) found that the performance of SMEs is positively affected by the high levels of education of the SME owners. SME owners that are highly educated are able to attain and develop skills to start up a new business and to sustain the business.

Most of the respondents were the SME owner or both the manager and owner (69\%). This is reflective of the fact that many SME owners perform many roles. Close corporation $(45.83 \%)$ and private limited company $(40.28 \%)$ were the popular choices for legal status of the business. In SA, SMEs stretch across all sectors of the economy (FinMark, 2010), while the survey results show that the SMEs stretch across most of the sectors. All of the SMEs surveyed are registered business with a legal status. Literature on SMEs and their legal status indicate that a big proportion of SMEs operate informally, without being registered (DTI, 2005).

The results on the number of people employed shows that almost all of the respondents meet the definition of SMME or SME, as stated by the National Small Business Act 1966, No. 102 of 1966, p. 17. More than a third of the SMEs employ between 5 to 20 people (Table 3).

The survey response reflects that majority $(86.11 \%)$ of the SMEs have been in business for more than 5 years. Majority of South African SMMEs remain in the embryonic state and baby business phases, which is less than 3.5 years since startup, lacking growth (DTI, 2008).

More than half of the SME owners/managers (56.52\%) have indicated that the performance of the business over the past year, in comparison to the previous year, has improved (Table 3). Whilst the performance of the business may have improved, majority of the SME owners/managers found that running an SME was more difficult.

Table 3. Background information of the participated SMEs

\begin{tabular}{|c|c|c|}
\hline Variables & Frequency & Percentage \\
\hline \multicolumn{3}{|l|}{ Legal status of your business } \\
\hline Private limited company & 30 & 40.54 \\
\hline Close corporation & 34 & 45.95 \\
\hline Partnership & 2 & 2.70 \\
\hline Sole proprietor & 5 & 6.76 \\
\hline Other & 3 & 4.05 \\
\hline \multicolumn{3}{|l|}{ Which sectors does your business trade in? } \\
\hline Agriculture & 1 & 1.35 \\
\hline Manufacturing & 16 & 21.62 \\
\hline Construction, mining & 10 & 13.51 \\
\hline Business services & 9 & 12.16 \\
\hline Tourism \& leisure & 5 & 6.76 \\
\hline Finance & 3 & 4.05 \\
\hline Transport, communication & 8 & 10.81 \\
\hline Health care, education, social services & 5 & 6.76 \\
\hline Wholesale, motor vehicles and repairs & 0 & 0.00 \\
\hline Customer services & 2 & 2.70 \\
\hline Retail industry & 1 & 1.35 \\
\hline Other & 14 & 18.92 \\
\hline \multicolumn{3}{|l|}{ How many people do you employ? } \\
\hline Less than 5 employees & 17 & 22.97 \\
\hline 5 to 20 employees & 23 & 31.08 \\
\hline 21 to 50 employees & 18 & 24.32 \\
\hline 51 to 100 employees & 8 & 10.81 \\
\hline 101 to 200 employees & 3 & 4.05 \\
\hline More than 200 employees & 5 & 6.76 \\
\hline \multicolumn{3}{|c|}{ How long has your company been in operation? } \\
\hline Less than 3 years & 3 & 4.05 \\
\hline Between 3 and 5 years & 8 & 10.81 \\
\hline Between 5 and 10 years & 15 & 20.27 \\
\hline Between 10 and 15 years & 10 & 13.51 \\
\hline Over 15 years & 38 & 51.35 \\
\hline \multicolumn{3}{|c|}{ Business performance in the past year in comparison to the previous year } \\
\hline Improved & 40 & 56.34 \\
\hline Worsened & 19 & 26.76 \\
\hline Unchanged & 12 & 16.90 \\
\hline \multicolumn{3}{|c|}{ Running an SME over the past year in comparison to the previous year } \\
\hline More difficult & 50 & 70.42 \\
\hline Easier & 0 & 0.00 \\
\hline Stayed the same & 21 & 29.58 \\
\hline
\end{tabular}

3.1. Internal factors. The internal factors that are discussed below are management competency and skills, access to finance and technological capabilities (Table 4).

Table 4. Summary of managerial skills of SMEs in $\mathrm{KZN}$, SA (\%)

\begin{tabular}{|l|c|c|}
\hline \multicolumn{1}{|c|}{ Variables } & Yes & No \\
\hline Owner/management having the necessary experience and training \\
\hline $\begin{array}{l}\text { Does management/owner have prior experience in } \\
\text { managing this type of business? }\end{array}$ & 66.67 & 33.33 \\
\hline
\end{tabular}


Table 4 (cont.). Summary of managerial skills of SMEs in KZN, SA (\%)

\begin{tabular}{|l|c|c|}
\hline \multicolumn{1}{|c|}{ Variables } & Yes & No \\
\hline $\begin{array}{l}\text { Does management/owner have prior experience in small } \\
\text { business management? }\end{array}$ & 69.01 & 30.99 \\
\hline $\begin{array}{l}\text { Does management/owner have formal training in business } \\
\text { management? }\end{array}$ & 55.71 & 44.29 \\
\hline $\begin{array}{l}\text { Does management/owner have formal training in financial } \\
\text { management and planning? }\end{array}$ & 54.29 & 45.71 \\
\hline $\begin{array}{l}\text { Does management/owner have formal training in } \\
\text { marketing? }\end{array}$ & 47.89 & 52.11 \\
\hline $\begin{array}{l}\text { Does management/owner have formal training in } \\
\text { bookeeping and accounting? }\end{array}$ & 48.53 & 51.47 \\
\hline Management/owner having the necessary skills to undertake the following \\
\hline Prepare financial statements & 43.48 & 56.52 \\
\hline Prepare trading budgets & 65.22 & 34.78 \\
\hline Prepare cash flow forecasts & 63.24 & 36.76 \\
\hline Analyse financial statements & 70.59 & 29.41 \\
\hline Do you outsource any of the business functions? & 69.44 & 30.56 \\
\hline If yes to outsourcing, then which of the following functions is outsourced? \\
\hline Accounting & 35 & 67.31 \\
\hline Human Resources & 3 & 5.77 \\
\hline IT & 9 & 17.31 \\
\hline Marketing & 0 & 0.00 \\
\hline Other & 5 & 9.62 \\
\hline
\end{tabular}

3.2. Managerial competency and skills. The study revealed that more than half $(59.16 \%)$ of the respondents viewed managerial competency and skills shortage as a factor that affects the performance of the business. This finding is supported by the Hisrich \& Drnovsek (2002). In their study, it was found that managerial competencies positively impact on the performance of SMEs and further, pointed out by Martin \& Staines (2008) SME failure is a result of lack of managerial experience.

Managerial competency/skills are summarized in Table 4. The results indicated that SME owners/managers lack prior experience in managing this type of business $(31.34 \%)$ and lack experience in small business management $(30.43 \%)$. If SMEs are to survive, they must obtain the necessary skill. Most entrepreneurs often start a new enterprise, while ignorant of many key elements of running their own enterprises (Shepard, Douglas \& Shanley, 2000). With experience, entrepreneurs must be knowledgeable about all functional areas of business for survival and success (Lotz \& Marais, 2007; Sola, Teruel \& Solano, 2014).

The majority of the respondents were found to have the necessary skill to analyze financial statements, prepare trading budgets, prepare cash flows and prepare financial statements. In another study, it was found that small firm owner-managers have been found to have problems in reading financial language and understanding common terms and conventions used in financial reports (Abdel, Rowena \& Robyn, 2010).
By relying on outsourcing, SMEs can obtain the capabilities and competences they require from external service providers (Gilley, Greer \& Rasheed, 2004). The present study found that $70 \%$ SMEs outsource the business functions, with accountancy being the most outsourced function. Authors reported that the main reasons small businesses outsource accounting functions are that they lack necessary resources and skills required to carry out accounting functions within the organzation, they lack the expertise and specialized knowledge of the professional accountant (Yahya \& Susela, 2011).

3.3. Access to finance. Accessibility to finance is a major factor affecting the growth and success of SMEs, which can be attributed to many factors (Haron et al., 2013). More than two-thirds (72\%) of the SME owner/manager believe that access to finance is a major challenge affecting the growth of business (Table 5). In SA, access to finance has been singled out as major constraint, impeding the survival and growth of start-up SMEs (Mazanai \& Fatoki, 2012). Researchers reported that access to external to finance is a struggle for SMEs in South Africa particularly salient for firms in emerging economies (Berger \& Udell, 2006). However, the results of the study on difficulties in accessing finance shows that only half the SME owners/managers $(52.24 \%)$ experience difficulties in accessing finance (Table 5).

The present study showed that the main source of funding is equity $(34.33 \%)$ followed by short term debt $(31.34 \%)$ (Table 5). According to Beck \& Demirguc-Kunt (2006), business finance falls into two major groupings, namely equity finance and loan finance. With finance cited as a major constraint to SMEs growth and development, various sources ought to be explored by SMEs owners/managers to run their business.

Table 5. Summary of accessing finance by SMEs in $\mathrm{KZN}$, SA

\begin{tabular}{|l|c|c|}
\hline \multicolumn{1}{|c|}{ Variables } & Frequency & Percentage \\
\hline Access to finance is a major challenge that affects the growth of my business \\
\hline Strongly disagree & 5 & 7.25 \\
\hline Disagree & 14 & 20.29 \\
\hline Agree & 26 & 37.68 \\
\hline Strongly agree & 24 & 34.78 \\
\hline How is your business financed? & 24 & 34.78 \\
\hline Equity & 22 & 31.88 \\
\hline Short term debt & 5 & 7.25 \\
\hline Long term debt & 6 & 8.70 \\
\hline Venture capital & 12 & 17.39 \\
\hline Other & 37 & 53.62 \\
\hline Does your business experience difficulties in accessing external finance? \\
\hline Yes & 32 & 46.38 \\
\hline No
\end{tabular}


The survey results indicate, from all the factors considered to make access to finance difficult, lack of collateral $(66 \%)$ and high interest rates (66\%) appear to the main reasons (Figure 1). In SA, the risk perception on SMEs in associated with the high failure rates. Strict security requirements are one of the ways through which financial institutions attempt to shield themselves against such risks (Mazanai \& Fatoki, 2012). As Okpara \& Kabongo (2009) rightly pointed out, one of the major reasons for the difficulty of borrowing money from the bank is because of lack of required collateral to be used as security against the borrowed funds.

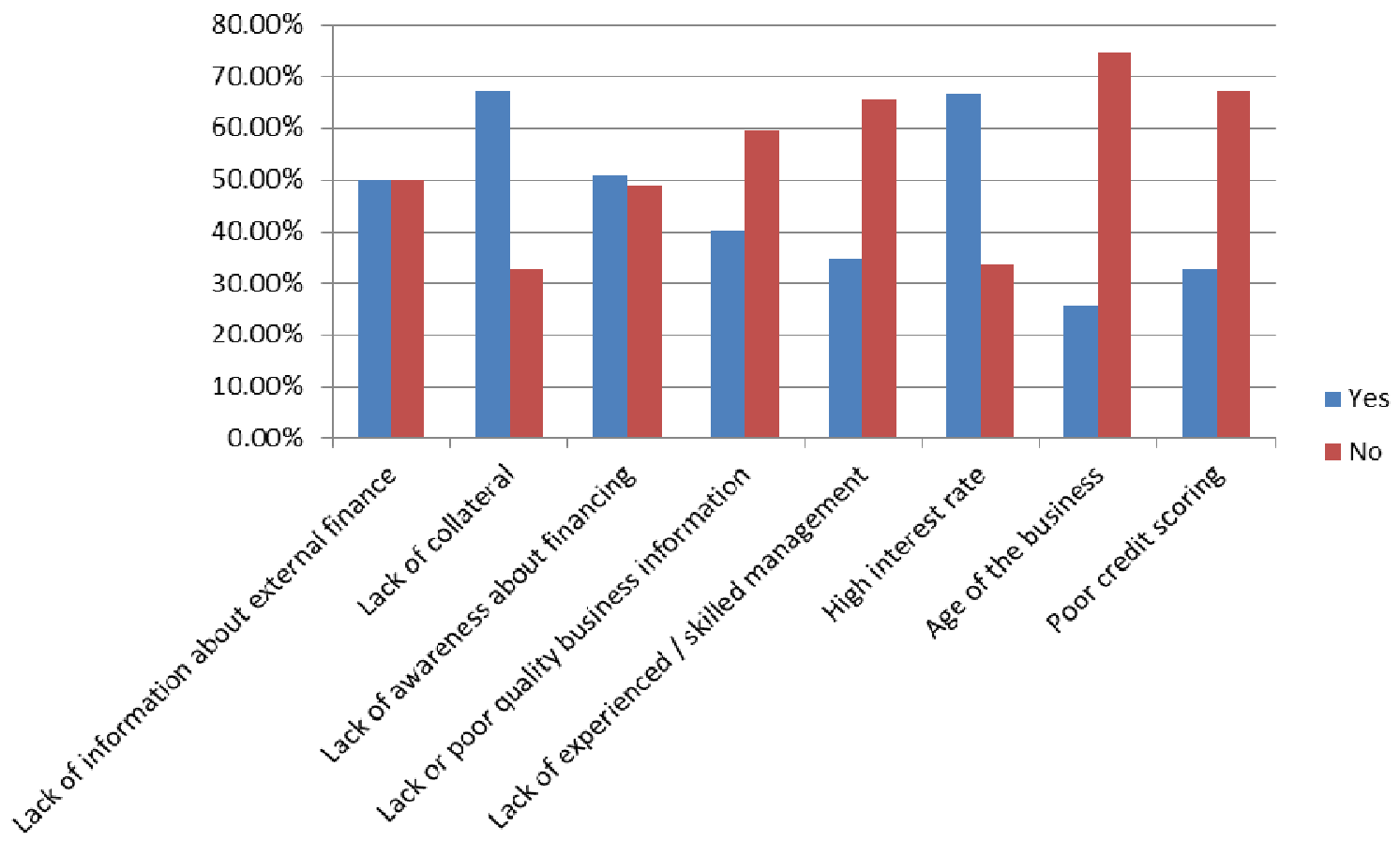

Fig. 1. Reasons for difficulties with access to finance by SMEs in KZN, SA

3.4. Technological advancement. Majority of the SME owners/managers $(81.82 \%)$ believe that technological advancement will improve performance. This result is supported by studies carried out by Levey \& Powell (2000). The authors stated that application of technology adoption of IT will assist an organization in storing information, as well as communicating with customer, suppliers and business partner who will facilitate business transaction, and enhance the overall performance of SMEs, leading to a better performance in reducing the operating expenses as a whole (Levey \& Powell, 2000). Arinaitwe (2006) mentioned that primary reasons small business continue to face growth challenges in developing countries, despite significant support from governments and other organizations is their technological capabilities or lack thereof.

\subsection{External environment factors.}

3.5.1. Competition. Competition is viewed as one of the major challenges affecting the performance of SMEs by most (74\%) of the SME owners/managers. In Finscope survey (2010), competition ranked as the third greatest obstacle to growth for businesses. More than half (62\%) respondents saw local competitors as a challenging factor (Table 6). Over the years, competition among SMEs has increased radically (Gunasekaran, Rai \& Griffin, 2011), which is the position on KZN. Literature dealing with SMEs and competition states that global competition confronts the majority of purely domestic SMEs, products of which and sales are extremely localized. Local SMEs find it increasingly difficult to survive or even maintain their current business position in their respective markets (Singh, Garg \& Deshmukh, 2010).

Table 6. Participants views regarding competition as a factor in SMEs in KZN, SA

\begin{tabular}{|l|c|c|}
\hline \multicolumn{1}{|c|}{ Variable } & Frequency & Percentage \\
\hline \multicolumn{3}{|c|}{ Is competition a major challenge that confronts your business? } \\
\hline Yes & 48 & 73.85 \\
\hline No & 17 & 26.15 \\
\hline Which one is regarded as business competitors? & \\
\hline Local competitors & 41 & 62.12 \\
\hline Foreign competitors & 6 & 9.09 \\
\hline Both & 19 & 28.79 \\
\hline
\end{tabular}

3.5.2. Globalization. Globalization is not viewed as a major challenge affecting their business by a large proportion of the survey respondents (57\%) (Figure 2). Globalization and trade liberalization have ushered in new opportunities, as well as challenges for SMEs. Presently, only a small part of the SME sector is able to identify and exploit these opportunities and deal with the challenges (OECD, 2004). Only about $40 \%$ of SMEs in KZN are 
affected by globalization. This could mean the SMEs in KZN may have not as yet identified the opportunities or challenges of globalization.

3.5.3. SA labor laws. Almost three quarter of the survey respondents see SA labor laws as affecting the growth of the business (Figure 2). SA's labor policies are considered to be extremely restrictive and the new labor regulations being promulgated have been slated as being even more restrictive than the existing problematic policies that were in place. Labor market regulations play a significant role in the cost structure of SMEs. Strict labor laws on the hiring and firing decisions of the firm can make it costly for the SMEs and encourage them to employ workers without proper registration.

3.5.4. Tax laws. The survey results revealed that twothirds of the SME owners/managers (67.74\%) believe that tax laws are affecting the growth of the business (Figure 2). This is consistent with the findings of past research, where tax compliance costs for SMMEs are viewed to have negative impacts on SMMEs (Venter \& de Clercq, 2007). The most difficult areas for compliance have been singled out as income tax and VAT (Mollentz, 2002). Tax requirements add to the administrative burden of small businesses and use resources that could, otherwise, be used for managing such businesses more effectively (Abrie \& Doussy, 2006).
3.5.5. BEE laws. The lack of information and understanding of the BEE demands and possibilities became a fundamental problem and undermined its credibility (Sanchez, 2006). The result revealed that more than half the respondents $(58.73 \%)$ strongly agreed that BEE laws are affecting the growth of the business (Figure 2). With more than $80 \%$ of the respondents being White or Asian, SMEs in KZN maybe experiencing challenges in finding a suitable Black partner or skilled Black managers to fulfill the management goals.

3.5.6. Government bureaucracy. Majority of the SME owners/managers (72.58\%) believed that government bureaucracy have an impact on the growth of the business (Figure 2). This result is supported by studies where it was found that SMEs are a key indicator of the impact of regulation as smaller companies have less ability to absorb compliance costs than bigger firms (Christianson, 2003). Regulations governing establishment of businesses are extremely intricate and conflicting. Therefore, small businesses find it so complicated to conform to, as the South African government has invented new methods of bureaucracy which are considered as the most important hindrance for small firms to conduct or establish business in SA (Small Business Project, 2003).

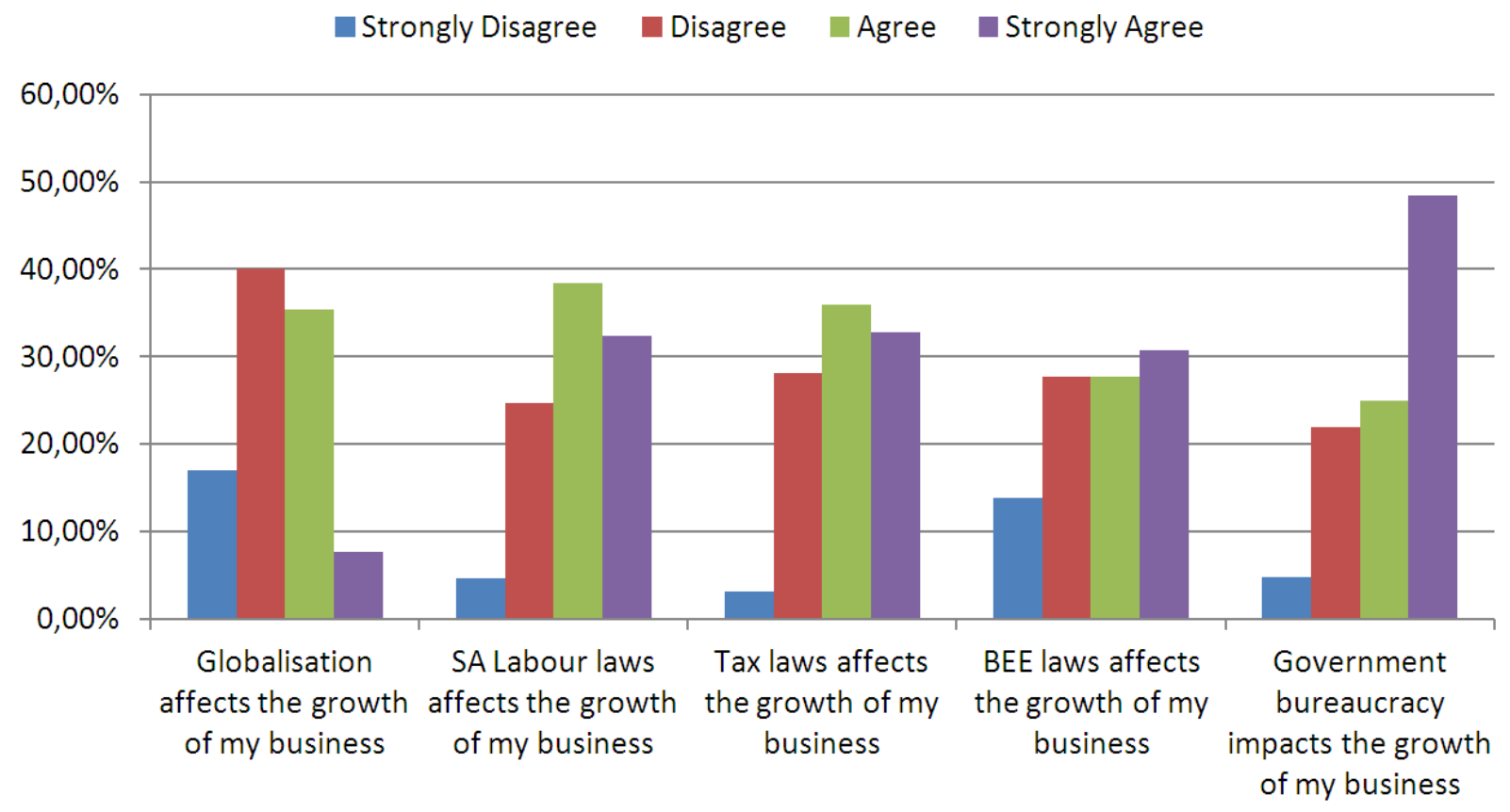

Fig. 2. Participants views regarding globalization, regulation and government bureaucracy impacting SMEs in KZN, SA

3.5.7. Macroeconomic factors. Majority of the SME owners/managers (more than $80 \%$ ) to the survey reveal that the strength of the rand, inflation rate and interest rate all affect the business performance (Figure 3). Macroeconomic factors are affecting the business performance. The research results are aligned to characteristics associated with the South African economy. Weak rand and high inflation rates are some of the characteristics of South Africa economic environment (Ehlers \& Lazenby, 2007). A weakening rand may be harmful to business profits, for an SME is involved in imports. 


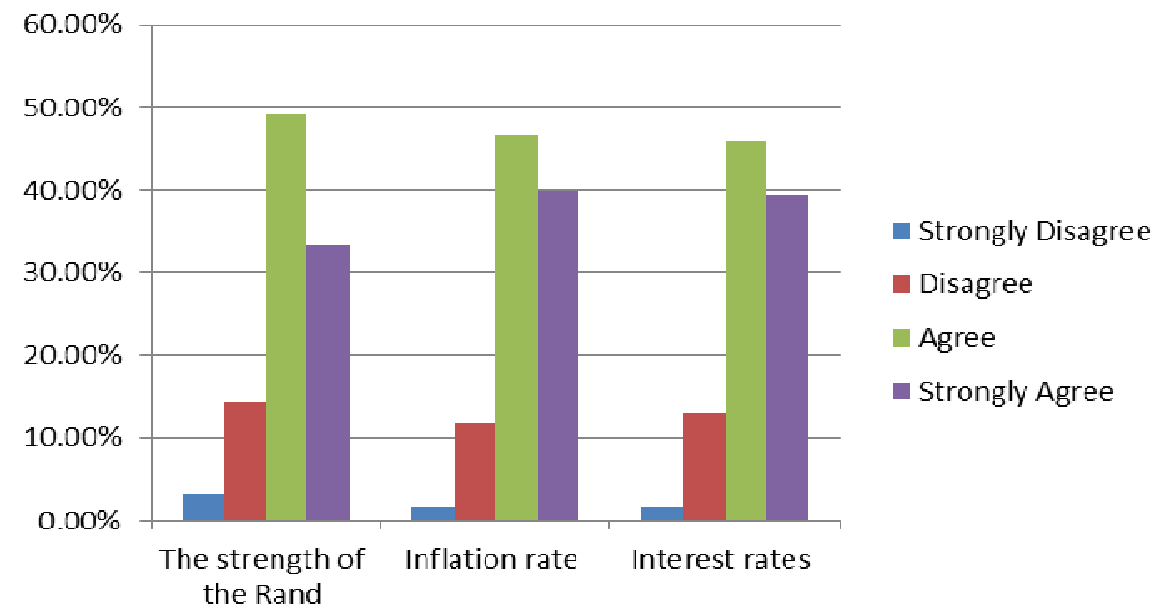

Fig. 3. Participants response with regards to macroeconomic factors

3.5.8. Infrastructure. Okapar \& Kabonga (2009) stated, in their study, that infrastructure factors such as power supply and access roads were major factors. However, the research results show that the SME owners/managers see power supply and telecommunication infrastructure as affecting the business performance. A sufficiently functioning infrastructure in terms of providing services, such as power, is another factor that contributes to SME growth. The role of services such as electricity, transportation, and water sanitation are critical in a country's development and are directly linked to small business success and economic growth (Okpara \& Kabongo, 2009). In KZN, more than $70 \%$ of the SMEs find that power supply is affecting their performance (Figure 4). This means that the success and economic growth remains to be affected, while the province continues to struggle with the power supply.

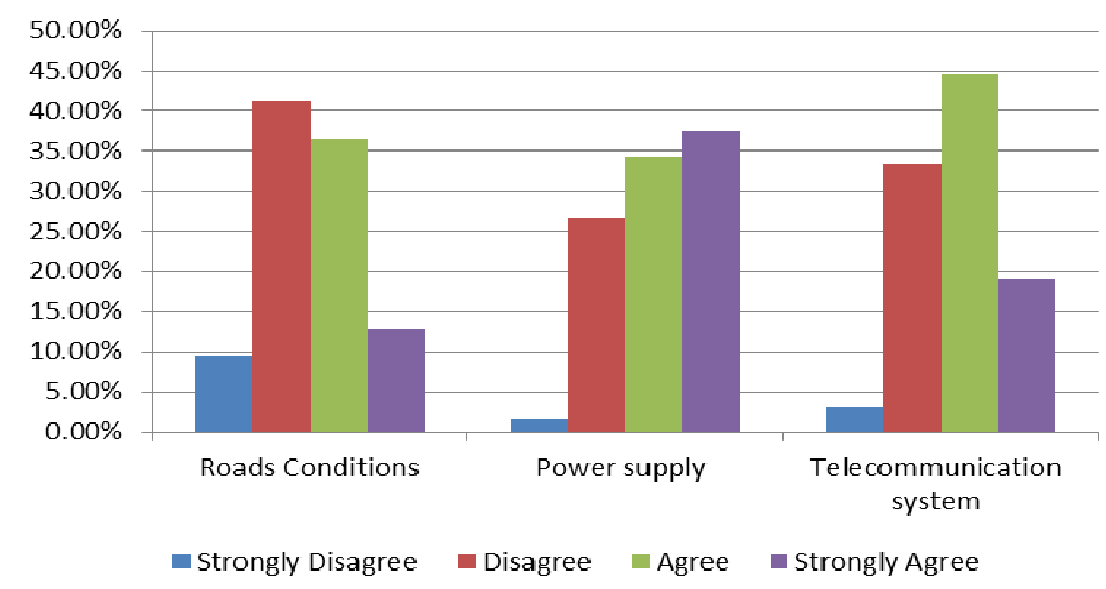

Fig. 4. Participants response with regards to infrastructure

3.5.9. Crime and corruption. Small businesses are a big target for crime, because they often lack the ability to detect the illegal actions of employees or professional thieves and the processes to prevent theft and fraud. The survey results showed that majority of the SME owners/managers $(88.89 \%)$ view crime and corruption as a major factor affecting business performance (Figure 5).

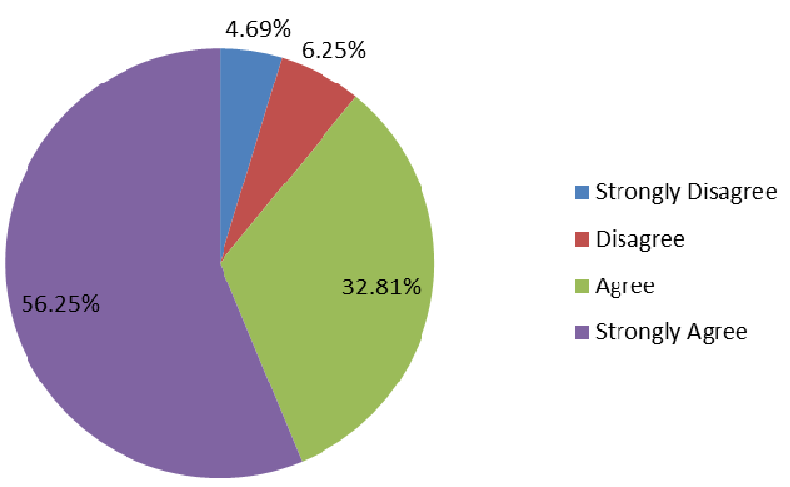

Fig. 5. Crime and corruption affects the growth of the business 
Finally, to establish significant factor for SMEs performance over the last year, all the internal and external variables were considered. The present study revealed that there was a statistically significant association existing between competition and performance of the business $(p=0.011)$. All of the SME owners/managers (100\%) whose business performance worsened in the past year mentioned that completion is a major challenge. Majority of SME owners/managers $(66.67 \%)$ who indicated that SME performance had improved compared to the previous year also indicated that competition was a major challenge (Table 7). SMEs in KZN are faced with competition which is impacting the performance of the business negatively. SMEs are finding it difficult to maintain their market share and position, due to the competition from local competitors, as well as international competitors. SMEs in KZN need to equip themselves and position themselves to deal both domestic and international competition.

Table 7. Association between competition and business performance

\begin{tabular}{|c|c|c|c|c|c|c|}
\hline & & \multicolumn{3}{|c|}{ Is competition a major challenge that confronts your business? } & \multirow{2}{*}{ Chi-squared value } & \multirow{2}{*}{$P$ value } \\
\hline \multirow{4}{*}{$\begin{array}{l}\text { How was your business } \\
\text { performance in the past year in } \\
\text { comparison to the previous year? }\end{array}$} & & Yes & No & Row totals & & \\
\hline & Improved & 24 & 12 & 36 & \multirow{3}{*}{9.008} & \multirow{3}{*}{0.011} \\
\hline & Worsened & 17 & 0 & 17 & & \\
\hline & Unchanged & 6 & 5 & 11 & & \\
\hline
\end{tabular}

\section{Conclusions}

The present study highlighted several factors in the internal environment, such as technological capabilities, managerial competence and skills and access to finance, that are found to affect SMEs in South Africa. With regards to external factors, regulatory factors, macroeconomic factors, competition, globalization, and crime and corruption were found to be a major challenge for SMEs in SA. The findings of the research revealed that there was a significant association between the performance of SMEs in comparison to the previous year and competition. The external environment factor competition can be viewed as a major challenge affecting the performance of SMEs in KwaZulu-Natal.

\section{Limitations of the study}

The main constraint identified in this study was the poor response rate of the SMEs selected as the sample. Only $20.8 \%$ of the participants who received the online survey questionnaire completed it. This low completion rate could be due to time factor to complete the survey, and some respondents might not be comfortable to share information via the internet. Another limitation of the research was that it was only conducted in KwaZulu-Natal. The sample chosen does not represent the sample frame of all SMEs in KwaZulu-Natal. As such, a database for SMEs does not exist. This could be considered as a further limitation.

\section{Recommendations}

The recommendations below could be considered by SMEs in KZN, SA to overcome competition as a factor affecting their performance:

- To be able to confront competition, collaboration between SMEs can be considered. By entering into joint ventures, the opportunity to combine strengths, information and technological capabilities to increase sales or to enhance their customer base.

- SMEs need to continuously evaluate the environment that they operate in, understanding their competitors and their offerings/service. SME competitiveness depends largely on the speed with which new products can be brought to the market place.

- SMEs in KwaZulu-Natal to be able to confront competition from local and foreign competitors, from developed and emerging economies, need to look into the opportunities these economies will provide.

- Future researches could perform an in-depth study on the external factor competition, addressing the impact on the performance of SMEs.

\section{References}

1. Abdel, K.H., Rowena, B. \& Robyn, D. (2010). Understanding financial information used to assess small firm performance, Qualitative Research in Accounting \& Management, 7 (2), pp. 163-179.

2. Abrie, W. \& Doussy, E. (2006). Tax compliance obstacles encountered by small and medium enterprises in South Africa, Research Journal of School of Accounting Sciences, 14 (1), pp. 1-13.

3. Alattar, J.M., Kouhy, R. \& Innes, J. (2009). Management accounting information in micro enterprises in Gaza, Journal of Accounting and Organizational Change, 5 (1), p. 81.

4. Arinaitwe, J.K. (2006). Factors Constraining the Growth and Survival of Small Scale Businesses. A Developing Countries Analysis, Journal of American Academy of Business, 8 (2), pp. 167-178.

5. Bayati, A. \& Taghavi, A. (2007). The impacts of acquiring ISO 9000 certification on the performance of SMEs in Tehran, The TQM Magazine, 19 (2), pp. 140-149. 
6. Beck, T. \& Demirguc-Kunt, A. (2006). Small and Medium Size Enterprise: Access to Finance as a Growth Constraint, Journal of Banking \& Finance, 30 (1), pp. 2931-2943.

7. Berger, A.N. \& Udell, G.F. (2006). A more complete conceptual framework for SME finance, Journal of Banking \& Finance, 30 (11), pp. 2945-2966.

8. Cacciotti, G. and Hayton, J.C. (2015). Fear and Entrepreneurship: A Review and Research Agenda, International Journal of Management Reviews, 17 (2), pp. 165-190.

9. Cant, M.C. \& Wiid, J.A. (2013). Establishing the Challenges Affecting South African SMEs, International Business \& Economics Research Journal, 12 (6), pp. 707-716.

10. Chamberlain, D. \& Smith, A. (2006). Recent Findings on Tax-Related Regulatory Burden on SMMEs in South Africa. Working Paper 06/105, Development Policy Research Unit, University of Cape Town. Available at: http://www.thepresidency.gov.za/docs/pcsa/economic/smith1.pdf Accessed on 10 July 2014].

11. Christianson, D. (2003). The investment climate in South Africa - regulatory issues: some insights from the highgrowth export oriented SME sector. Paper prepared for DFID, London. Available at: http://siteresources.worldbank.org/INTWDRS/Resources/477365-1327693758977/8397896-1327771331430/dfid_ christianson_5.pdf. Accessed on 10 July 2014.

12. Corruption Watch. (201)3. CPI 2013 - South Africa in the African context. Avaialble at: http://www.corruptionwatch.org.za/content/cpi-2013-\%E2\%80\%93-south-africa-african-context Accessed on 15 July 2014.

13. Dalberg. (2011). Report on Support to SMEs in Developing Countries Through Financial Intermediaries. Available at: http://www.eib.org/attachments/dalberg_sme-briefing-paper.pdf. Accessed on 21 July 2014.

14. Delmar, F. \& Wiklund, J. (2008). The Effect of Small Business Managers' Growth Motivation on Firm Growth: A Longitudinal Study, Entrepreneurship Theory and Practice, 32 (3), pp. 437-457.

15. Department of Trade and Industry (DTI). (2005). Integrated Small Enterprise Development Strategy: Unlocking the Potential of South African Entrepreneurs. DTI, Pretoria.

16. Ehlers, T. \& Lazenby, K. (2007). Strategic Management: South Africa concept and cases. 2nd ed. Pretoria: Van Schaik.

17. Fang, N., Yuli, Z. \& Hongzhi, X. (2009). Acquisition of resources, formal organization and entrepreneurial orientation of new ventures, Journal of Chinese Entrepreneurship, 1 (1), pp. 40-52.

18. Fatoki, O. \& Garwe, D. (2010). Obstacles to the growth of new SMEs in South Africa: a principal component analysis approach, African Journal of Business Management, 4 (5), pp. 729-738.

19. FinMark. (2010). FinScope South Africa Small Business Survey (2010). Available at: http://www.finmark.org.za/wpcontent/uploads/pubs/FS-Small-Bu siness_-reportFNL2.pdf. Accessed on 10 July 2014.

20. Gilley, K.M., Greer, C.R. \& Rasheed, A.A. (2004). Human resource outsourcing and organizational performance in manufacturing firms, Journal of Business Research, 57 (3), pp. 232-240.

21. Gunasekaran, A., Rai, B.K. \& Griffin, M. (2011). Resilience and competitiveness of small and medium size enterprises: an empirical research, International Journal of Production Research, 49 (18), pp. 5489-5509.

22. Haron, H., Said, S.B., Jayaraman, K. \& Ismail, I. (2013). Factors Influencing Small Medium Enterprises (SMES) in Obtaining Loan, International Journal of Business and Social Science, 4 (15), pp. 182-195.

23. Herrington, M., Kew, J. \& Kew, P. (2010a). Tracking Entrepreneurship in South Africa: A GEM Perspective. Available at: http://www.africanentrepreneur.com/images/library/pdf/GEM\%20SA\%202009\%20-\%20Tracking\% 20Entrepreneurship.pdf. Accessed on 15 July 2014.

24. Herrington, M., Kew, J. \& Kew, P. (2010b). Global Entrepreneurship Monitor. Available at: http://www.gemconsortium.org/docs/download/605. Accessed on 30 July 2014.

25. Hisrich, R.D. \& Drnovsek, M. (2002). Entrepreneurship and Small Business Research, Journal of Small Business and Enterprise Development, 9 (2), pp. 172-222.

26. Ihua, U.B. (2009). SMEs Key Failure-factors: A Comparison between the United Kingdom and Nigeria, Journal of Social Science, 18 (3), pp. 199-207.

27. Joppe, M. (2000). The Research Process. Available at: http://www.htm.uoguelph.ca/MJResearch/rp.htm. Accessed on 21 September 2014.

28. Kolstad, I. \& Wiig, A. (2015). Education and entrepreneurial success, Small Business Economics, 44 (4), pp. $783-796$.

29. Levy, M. \& Powell, P. (2000). Information systems strategy in SMEs - An organizational perspective, Journal of Strategic Information Systems, 9 (1), pp. 63-84.

30. Lotz, O. \& Marais, L. (2007). Manufacturing enterprises and marketing planning in a mining area of the North West Province, South Africa: lessons for local business support centres, Development Southern Africa, 24 (5), pp. 693-706.

31. Longenecker, J.G., Petty, J.W., Hoy, F. \& Palich, L.E. (2012). Small Business Management, An entrepreneurial emphasis. 16th ed. London: Thomson South Western.

32. Maswanganyi, N. (2014). Economy: Weak rand will fuel inflation, higher interest rates, says Moodys, Business Day Live. Available at: http://www.bdlive.co.za/economy/2014/02/13/weak-rand-will-fuel-inflation-higherinterest-rates-says-moodys. Accessed on 03 June 2014.

33. Martin, G. \& Staines, H. (2008). Managerial competencies in small firm, Journal of Management Development, 13 (7), pp. 23-34.

34. Mollentz, J. (2002). Creating a Conducive Policy Environment for Employment Creation in SMMEs in South Africa, SEED Working Paper No. 35, International Labor Office, Geneva. Available at: 
http://www2.ilo.org/wcmsp5/groups/public/---ed_emp/---emp_ent/documents/publication/wcms_100918.pdf?origin= publication_detail. Accessed on 03 June 2014.

35. Mazanai, $\bar{M}$. \& Fatoki, O. (2012). Access to Finance in the SME Sector: A South African Perspective, Asian Journal of Business Management, 4 (1), pp. 58-67.

36. National Credit Regulator (NCR). (2011). Literature Review on Small and Medium Enterprises' Access to Credit and Support in South Africa. Available at: http://www.ncr.org.za/pdfs/Literature $\% 20$ Review\%20on\%20SME\%20Access\%20to\%20Credit\%20in\%20South\%20Africa_Final\%20Report_NCR_Dec\%202 011.pdf. Accessed on 23 June 2014.

37. OECD. (2004). Promoting Entrepreneurship and Innovative SMEs in a Global Economy, Second OECD Conference of Ministers responsible for Small and Medium-sized Enterprises (SMEs). Available at: http://www.oecd.org/cfe/smes/31919590.pdf. Accessed on 17 July 2014.

38. Okpara, J.O. \& Kabongo, J.D. (2009). An Empirical Evaluation of Barriers Hindering the Growth of Small and Medium Sized Enterprises (SMEs) in a Developing Economy, African Journal of Business and Economic Research, 4 (1), pp. 7-21.

39. Pretorius, M. \& Shaw, G. (2004). Business plan in bank-decision making when financing new ventures in South Africa, South African Journal of Economics and Management Science, 7 (2), pp. 221-242.

40. Scarborough, N.M., Wilson, D.L. \& Zimmerer, T.W. (2009). Effective Small Business Management. 9th ed. New Jersey: Pearson Education, Inc, Upper Saddle River.

41. Schindler, P.S. \& Cooper, R.D. (2006). Business Research Methods. United States: McGraw-Hill Irwin.

42. Shepard, D.A., Douglas, E.J. \& Shanley, M. (2000). Ignorance, external shocks, and risk reduction strategies, Journal of Business Venturing, 15 (5-6), pp. 393-410.

43. Singh, R.K., Garg, S.K. \& Deshmukh, S.G. (2010). The competitiveness of SMEs in a globalized economy: Observations from China and India, Management Research Review, 33 (1), pp. 54-65.

44. Small Business Project. (2003). A small business perspective on tax compliance, SME Alert. Available at: http://www.sbp.org.za/uploads/mediaSME_Alert_A_small_business_pespective_on_tax_compliance_October_2003.pdf. Accessed on 20 September 2014.

45. Sekaran, U. \& Bougie, R. (2010). Research methods for business: A skill building approach. 5th ed. West Sussex, UK: John Wiley \& Sons Ltd.

46. Sola, C.M., Teruel, P.J.G. and Solano, P.M. (2014). Trade credit and SME profitability, Small Business Economics, 42 (3), pp. 561-577.

47. Transparency International. (2008). Corruption Perceptions Index 2008. Available at: http://www.transparency.org/research/cpi/cpi_2008. Accessed on 15 July 2014.

48. The DTI. (2008). Annual Review of Small Business in South Africa 2005-2007, Department Trade and Industry Republic of South Africa. Available at: http://www.dti.gov.za/sme_development/docs/smme_report.pdf. Accessed on 15 July 2014.

49. United Nations Industrial Development Organzation (UNIDO). (2007). Corruption prevention to foster small and medium-sized enterprise development. Providing anti-corruption assistance to small businesses in the developing world, Fighting Corruption, 1, pp. 1-21.

50. Van Eeden, S., Viviers, S. \& Venter, D. (2003). A comparative study of selected problems encountered by small businesses in the Nelson Mandela, Cape Town and Egoli Metropoles, Management Dynamics, 12 (3), pp. 13-23.

51. Venter, J.M.P. \& de Clercq, B. (2007). Tax compliance burden for small, medium and micro establishments in the business services industry, South African Journal of Economic and Management Sciences, 10 (1), pp. 1-13.

52. World Bank. (2006). World Development Indicator Database. Available at: http://worldbank.org/WBSITE/EXTERNAL/DATASTATISTICS. Accessed on 15 July 2014.

53. Xavier, S.R., Kelley, D., Kew. J., Herrington, M. \& Vorderwuibecke, A. (2012). Global Entrepreneurship Monitor 2012 Global Report. Available at: http://www.gemconsortium.org/docs/download/2645. Accessed on 15 July 2014.

54. Yahya, K. \& Susela, D. (2011). Accounting Outsourcing and Firm Performance in Iranian SMEs, International Journal of Economics and Finance, 3 (4), pp. 181-192.

55. Zhang, S.S., van Doorn, J. \& Leeflang, P.S. (2014). Does the importance of value, brand and relationship equity for customer loyalty differ between Eastern and Western cultures? International business review, 23 (1), pp. $284-292$. 